Prepared in cooperation with the Alaska Department of Transportation and Public Facilities

\title{
Application of the Multi-Dimensional Surface Water Modeling System at Bridge 339, Copper River Highway, Alaska
}

Open-File Report 2009-1237 



\section{Application of the Multi-Dimensional Surface Water Modeling System at Bridge 339, Copper River Highway, Alaska}

By Timothy P. Brabets and Jeffrey S. Conaway

Prepared in cooperation with the

Alaska Department of Transportation and Public Facilities

Open-File Report 2009-1237

U.S. Department of the Interior

U.S. Geological Survey 


\section{U.S. Department of the Interior \\ KEN SALAZAR, Secretary}

\section{U.S. Geological Survey \\ Suzette M. Kimball, Acting Director}

U.S. Geological Survey, Reston, Virginia: 2009

For more information on the USGS-the Federal source for science about the Earth, its natural and living resources, natural hazards, and the environment, visit http://www.usgs.gov or call 1-888-ASK-USGS.

For an overview of USGS information products, including maps, imagery, and publications, visit http://www.usgs.gov/pubprod

To order this and other USGS information products, visit http://store.usgs.gov

Suggested citation:

Brabets, T.P., and Conaway, J.S., 2009, Application of the multi-dimensional surface water modeling system at Bridge 339, Copper River Highway, Alaska: U.S. Geological Survey Open-File Report 2009-1237, 28 p.

Any use of trade, product, or firm names is for descriptive purposes only and does not imply endorsement by the U.S. Government.

Although this report is in the public domain, permission must be secured from the individual copyright owners to reproduce any copyrighted material contained within this report. 


\section{Contents}

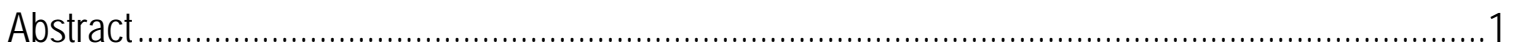

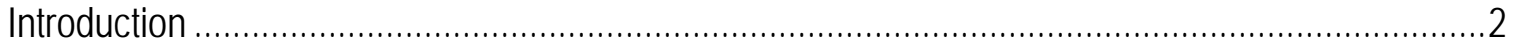

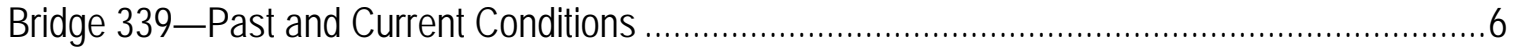

Potential Solutions to Scour and Erosion at the Bridge 339 Area ............................................15

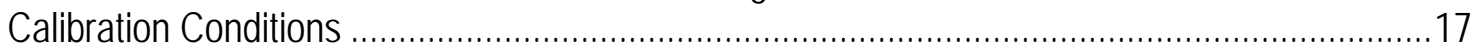

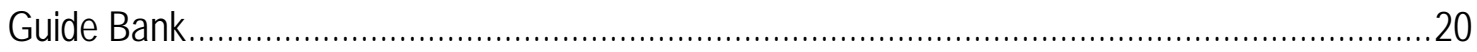

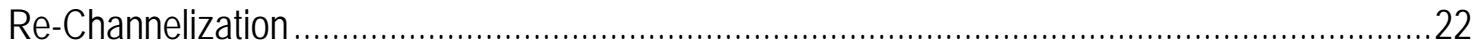

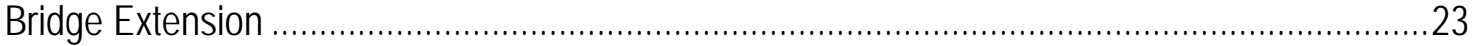

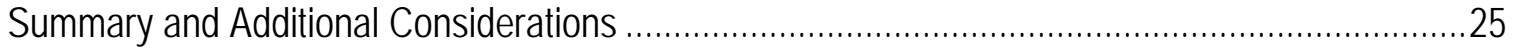

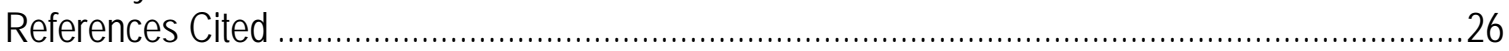

Appendix A.Input requirements and calibration procedures for the Multi-Dimensional

Surface Water Modeling System (MD_SWMS) as applied at Bridge 339 of the Copper

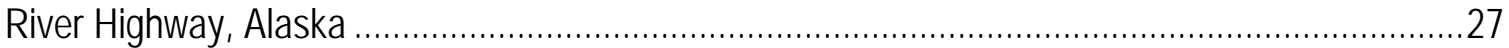

\section{Figures}

Figure 1. Map of the lower Copper River, Alaska.

Figure 2. Hydrograph for the Copper River at the Million Dollar Bridge near Cordova, Alaska showing average daily discharge for period of record $(1988-95,2005-08) \ldots \ldots \ldots \ldots \ldots \ldots \ldots \ldots . . .4$

Figure 3. Map showing locations of bridges along the Copper River Highway, Alaska ....................5

Figure 4. Bridge 339, Copper River Highway, August 6, 2004 .............................................6

Figure 5. Aerial photography of the lower Copper River near Bridge 339 taken in July 1996..........7

Figure 6. Aerial photography of the lower Copper River near Bridge 339 taken in August 2002 ......8

Figure 7. Aerial photography of the lower Copper River near Bridge 339 taken in October 2006 ....9

Figure 8. Aerial photography of the lower Copper River near Bridge 339 taken in August 2007 ....10

Figure 9. Photograph of the approach section to Bridge 339 showing the material that comprises the approach and the large riprap placed to protect the bank .........................11

Figure 10. Photograph of west approach section to Bridge 339, showing damage from the

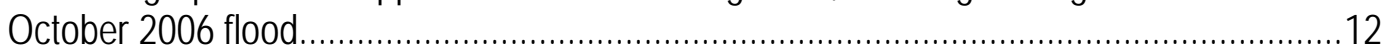

Figure 11. Aerial photography of the Bridge 339 area taken in October 2006...........................13

Figure 12. Photograph of Bridge 339 taken on September 29, 2008, looking upstream ...............14

Figure 13. Photograph of the Copper River Highway taken in August 2007, looking east towards Bridge 336 and Bridge 339 ................................................................15

Figure 14. Photograph of Bridge 339 taken in August 2007, looking upstream...........................16

Figure 15. Output from MD_SWMS showing velocity vectors at the Bridge 339 reach

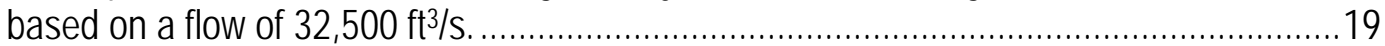

Figure 16. Output from MD_SWMS showing shear stress at the Bridge 339 reach

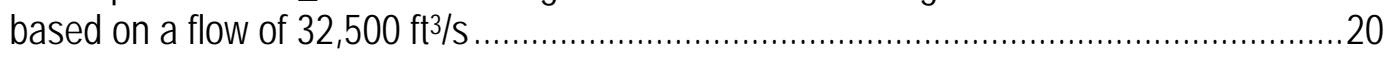

Figure 17. Output from MD_SWMS showing water-surface elevations at Bridge 339 based on a discharge of $32,500 \mathrm{ft} 3 / \mathrm{s}$ and construction of a $250 \mathrm{ft}$ guide bank .................21

Figure 18. Output from MD_SWMS showing velocity vectors at Bridge 339 based on a flow of $32,500 \mathrm{ft} 3 / \mathrm{s}$ and re-channelization upstream from bridge.

Figure 19. Output from MD_SWMS showing velocity vectors at Bridge 339 based on a flow of $32,500 \mathrm{ft}^{3} / \mathrm{s}$ and extending the bridge $240 \mathrm{ft}$ to the west 


\section{Table}

Table 1. Boundary conditions and model parameters used for the simulation of the calibration discharge of $32,500 \mathrm{ft}^{3} / \mathrm{s}$ at Bridge 339, Copper River Highway, Alaska

\section{Conversion Factors and Datums}

\section{Conversion Factors}

\begin{tabular}{lcl}
\hline \multicolumn{1}{c}{ Multiply } & \multicolumn{1}{c}{ By } & \multicolumn{1}{c}{ To obtain } \\
\hline foot $(\mathrm{ft})$ & Length & \\
mile (mi) & 0.3048 & meter $(\mathrm{m})$ \\
& 1.609 & kilometer $(\mathrm{km})$ \\
\hline square foot per second $\left(\mathrm{ft}^{2} / \mathrm{s}\right)$ & Area & \\
\hline square mile $\left(\mathrm{mi}^{2}\right)$ & 0.0929 & square meter per second $\left(\mathrm{m}^{2} / \mathrm{s}\right)$ \\
\hline & 2.590 & square kilometer $\left(\mathrm{km}^{2}\right)$ \\
\hline cubic yard $\left(\mathrm{yd}^{3}\right)$ & Volume & \\
\hline & 0.7646 & cubic meter $\left(\mathrm{m}^{3}\right)$ \\
\hline cubic foot per second $\left(\mathrm{ft}^{3} / \mathrm{s}\right)$ & Flow rate & \\
\hline
\end{tabular}

\section{Datums}

Vertical coordinate information is referenced to the North American Vertical Datum of 1988 (NAVD 88). Horizontal coordinate information is referenced to the North American Datum of 1983 (NAD 83). Altitude, as used in this report, refers to distance above the vertical datum. 


\title{
Application of the Multi-Dimensional Surface Water Modeling System at Bridge 339, Copper River Highway, Alaska
}

\author{
By Timothy P. Brabets and Jeffrey S. Conaway
}

\begin{abstract}
The Copper River Basin, the sixth largest watershed in Alaska, drains an area of 24,200 square miles. This large, glacier-fed river flows across a wide alluvial fan before it enters the Gulf of Alaska. Bridges along the Copper River Highway, which traverses the alluvial fan, have been impacted by channel migration. Due to a major channel change in 2001, Bridge 339 at Mile 36 of the highway has undergone excessive scour, resulting in damage to its abutments and approaches. During the snow- and ice-melt runoff season, which typically extends from mid-May to September, the design discharge for the bridge often is exceeded. The approach channel shifts continuously, and during our study it has shifted back and forth from the left bank to a course along the right bank nearly parallel to the road.

Maintenance at Bridge 339 has been costly and will continue to be so if no action is taken. Possible solutions to the scour and erosion problem include (1) constructing a guide bank to redirect flow, (2) dredging approximately 1,000 feet of channel above the bridge to align flow perpendicular to the bridge, and (3) extending the bridge. The USGS Multi-Dimensional Surface Water Modeling System (MD_SWMS) was used to assess these possible solutions. The major limitation of modeling these scenarios was the inability to predict ongoing channel migration. We used a hybrid dataset of surveyed and synthetic bathymetry in the approach channel, which provided the best approximation of this dynamic system. Under existing conditions and at the highest measured discharge and stage of 32,500 $\mathrm{ft}^{3} / \mathrm{s}$ and $51.08 \mathrm{ft}$, respectively, the velocities and shear stresses simulated by MD_SWMS indicate scour and erosion will continue. Construction of a 250-foot-long guide bank would not improve conditions because it is not long enough. Dredging a channel upstream of Bridge 339 would help align the flow perpendicular to Bridge 339, but because of the mobility of the channel bed, the dredged channel would likely fill in during high flows. Extending Bridge 339 would accommodate higher discharges and re-align flow to the bridge.
\end{abstract}




\section{Introduction}

The lower Copper River/Copper River Delta is a complex and dynamic system. Near its mouth, the Copper River drains approximately $24,000 \mathrm{mi}^{2}$, making it the third largest basin in the State of Alaska (fig. 1). During the winter months (November through April), the river is ice covered and flow averages $11,700 \mathrm{ft}^{3} / \mathrm{s}$. During the open water months, May through October, snowmelt and glacier melt contribute significant flow to the Copper River and average flow increases by an order of magnitude- to $113,000 \mathrm{ft}^{3} / \mathrm{s}$ (fig. 2).

The Copper River Highway begins at Cordova and heads about 48 mi northeast to the Million Dollar Bridge. Eleven bridges are located along the highway as it extends across the delta (fig. 3). Channels in the large delta are constantly scoured and filled, and flow shifts from one channel to another. As a result, several bridges have been damaged by excessive scour. For example, Bridge 342 has undergone major reconstruction (adding 480 feet to the original bridge and constructing spur dikes) due to a combination of channel migration, changes in flow regime, and severe scour.

The purpose of this report is to (1) provide a brief history and overview of the recent channel changes at Bridge 339 that have resulted in higher flows at the bridge, and (2) analyze the hydraulic conditions at the bridge at a discharge of $32,500 \mathrm{ft}^{3} / \mathrm{s}$ and how those conditions would be affected if different betterments were put in place. These betterments included riprap reinforcement, a guide bank, re-channelization, and lengthening the bridge. 


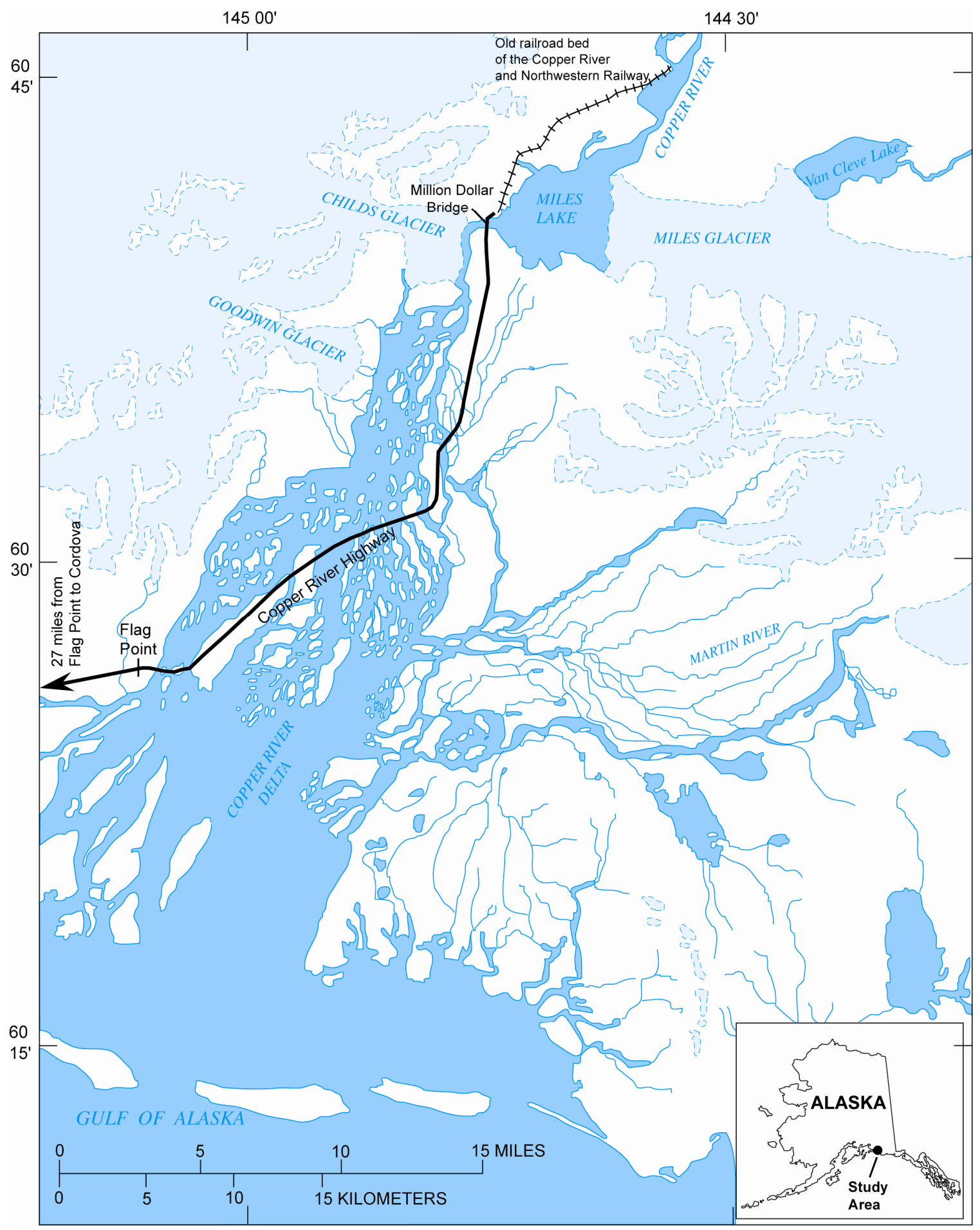

Figure 1. Map of the lower Copper River, Alaska. 


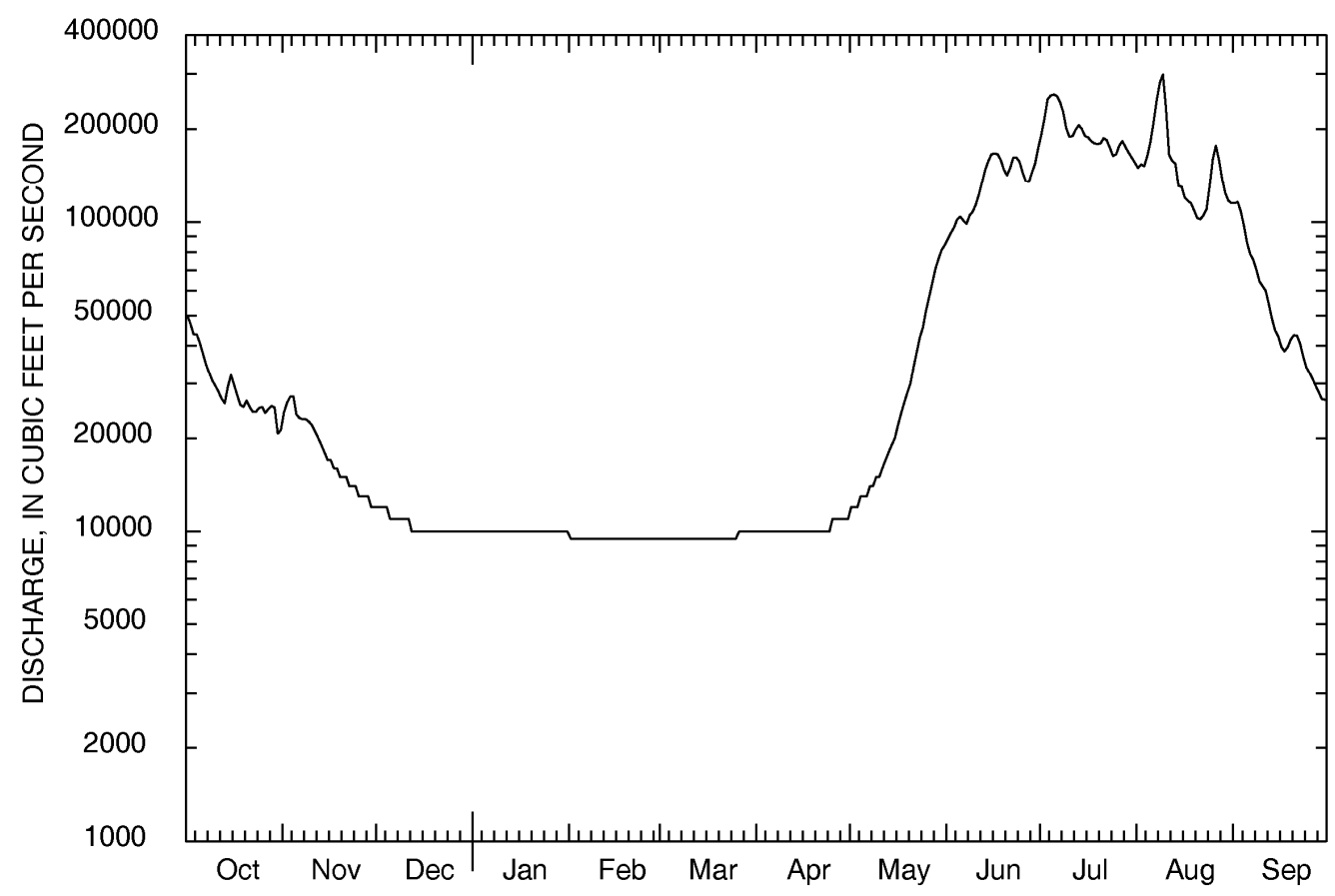

Figure 2. Hydrograph for the Copper River at the Million Dollar Bridge near Cordova, Alaska showing average daily discharge for period of record (1988-95, 2005-08). 


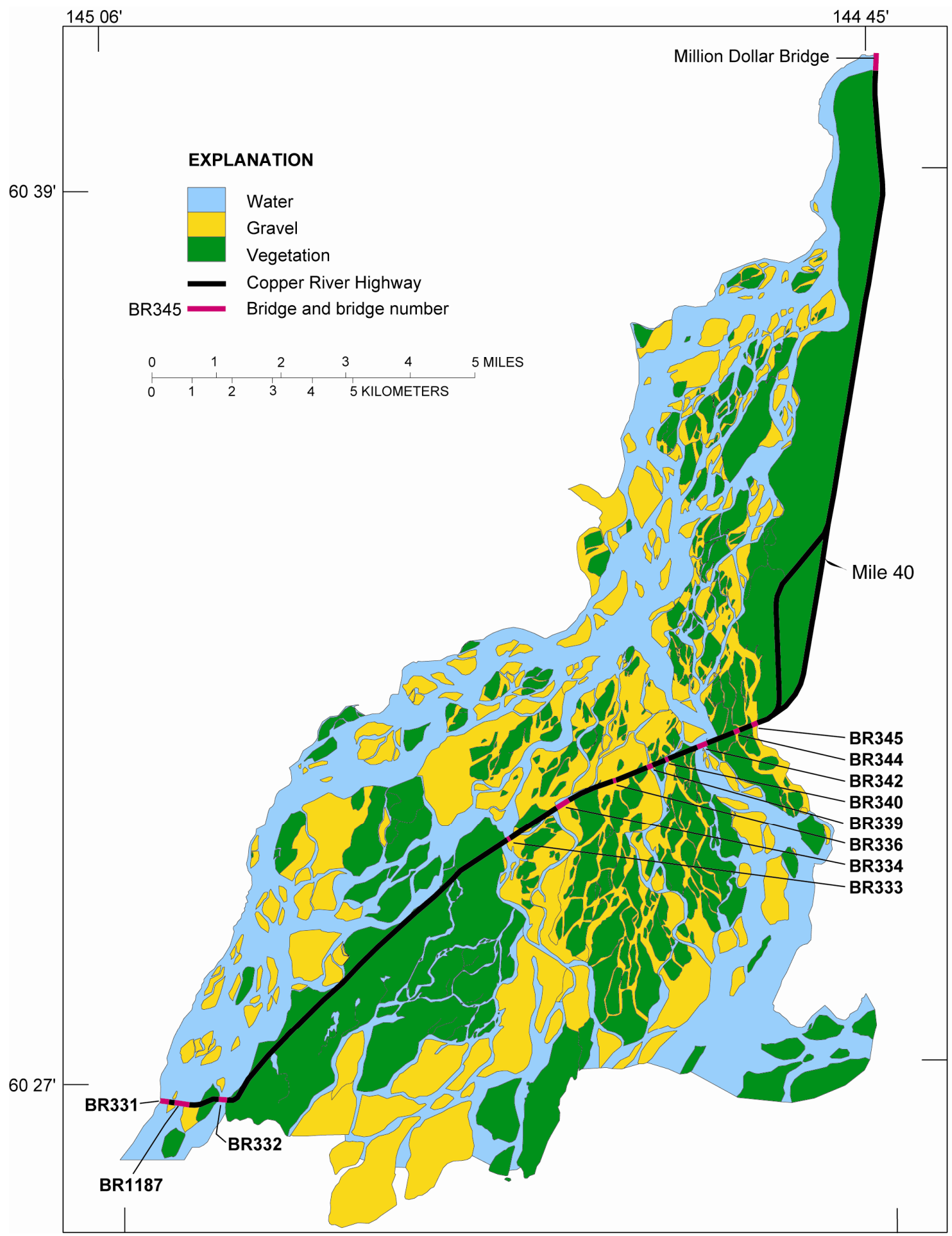

Figure 3. Map showing locations of bridges along the Copper River Highway, Alaska. 


\section{Bridge 339-Past and Current Conditions}

The bridges from Flag Point to the Million Dollar Bridge were damaged in the 1964 earthquake. Beginning in 1970, as part of a major reconstruction effort, all the bridges were rebuilt. Bridge 339 was designed for a flow of 17,500 ft $3 / \mathrm{s}$ and rebuilt during 1976-78. When completed, the bridge was $400 \mathrm{ft}$ long and supported by four sets of concrete-filled steel piers spaced $80 \mathrm{ft}$ apart (fig. 4).

Flow and channel characteristics of the lower Copper River from 1950 to 1995 were documented in an earlier USGS study (Brabets, 1997). The study found that of the total flow of the Copper River that passed through the Million Dollar Bridge, approximately 50 percent passed through the bridges at Flag Point (Bridges 331, 1187, and 332) and approximately 40 percent passed through Bridge 342 (fig. 3). The remaining flow passed through the other bridges and the percentage of flow that passed through Bridge 339 ranged from less than 1 to 5 percent of the total flow $-1,000 \mathrm{ft}^{3} / \mathrm{s}$ to $14,600 \mathrm{ft}^{3} / \mathrm{s}$ - well below the design discharge for the bridge.

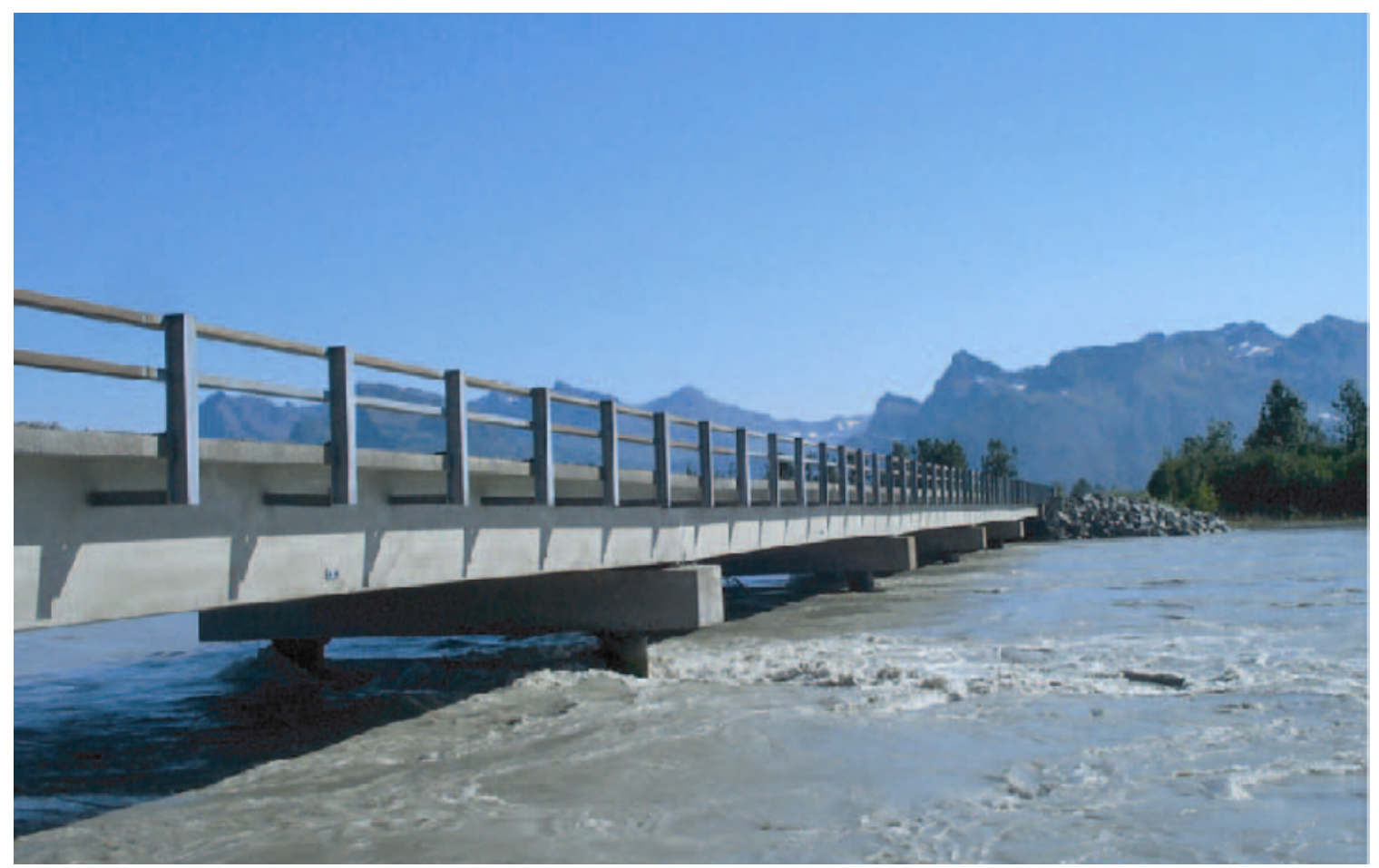

Figure 4. Bridge 339, Copper River Highway, August 6, 2004. (Discharge is 27,200 ft3/s.) 
The flow conditions at Bridge 339 documented by the USGS remained the same until 2001, based on aerial photography taken in 1996 and records of the Alaska Department of Transportation and Public Facilities (AKDOT\&PF) Cordova maintenance office. In 2001, most likely due either to high flow in the Copper River or to the effects of ice jams, a major channel change occurred at the bridge. A comparison of aerial photography flown in 2002 with aerial photography flown in 1996 clearly showed the channel change (figs. 5-6). A fairly large sinusoidal (S-shape) channel formed towards Bridge 339.

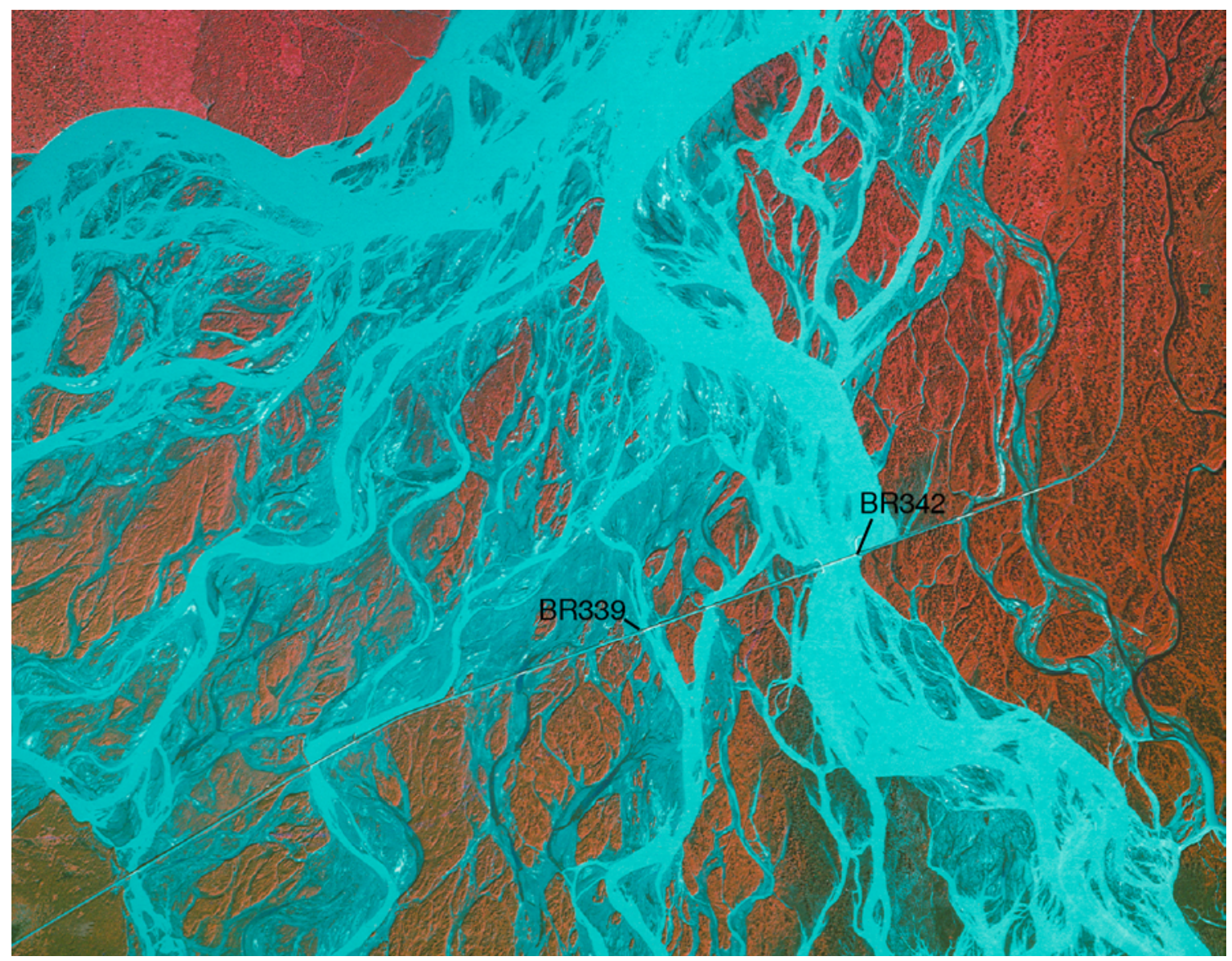

Figure 5. Aerial photography of the lower Copper River near Bridge 339 taken in July 1996. 


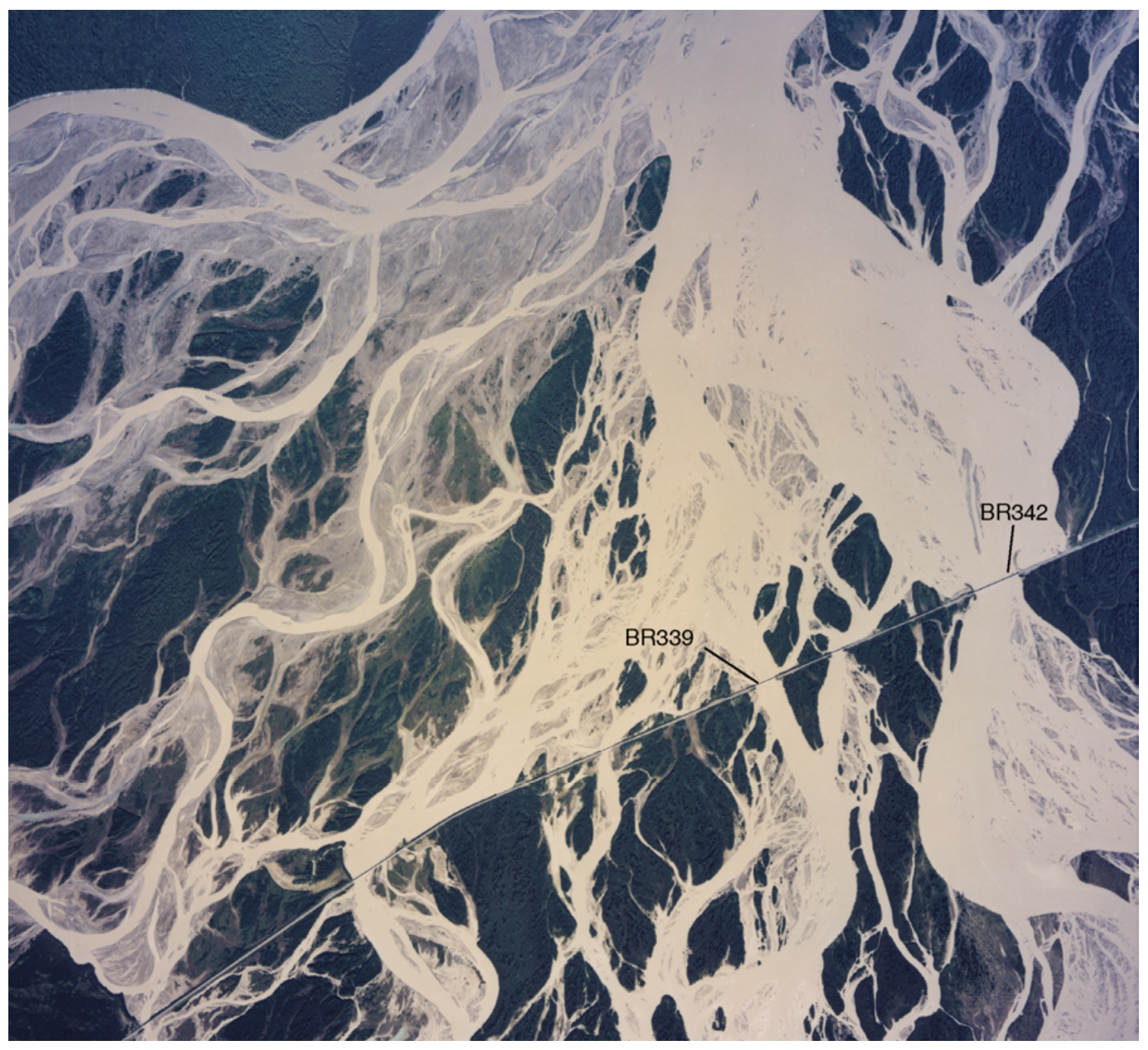

Figure 6. Aerial photography of the lower Copper River near Bridge 339 taken in August 2002. 
From 2002 to 2009, the main channel to Bridge 339 has been constantly changing. LIDAR (Light Detection and Ranging) imagery obtained in 2005 and aerial photography flown in 2006 and 2007 (figs. 7-8) show the channel migrating toward the west and impacting the approach to the bridge. The channel then reverses direction and then heads eastward, parallel to the approach, and then flows under the bridge. Because of the changing direction of the channel, the angle of attack, and the foundation material beneath the approach to Bridge 339 (fig. 9), large quantities of riprap have been needed to stabilize the approach; in most instances, this provided only temporary bank stabilization during the summer runoff months. Since 2004, approximately $10,000 \mathrm{yd}^{3}$ of large riprap have been placed along the approach by AKDOT\&PF personnel.

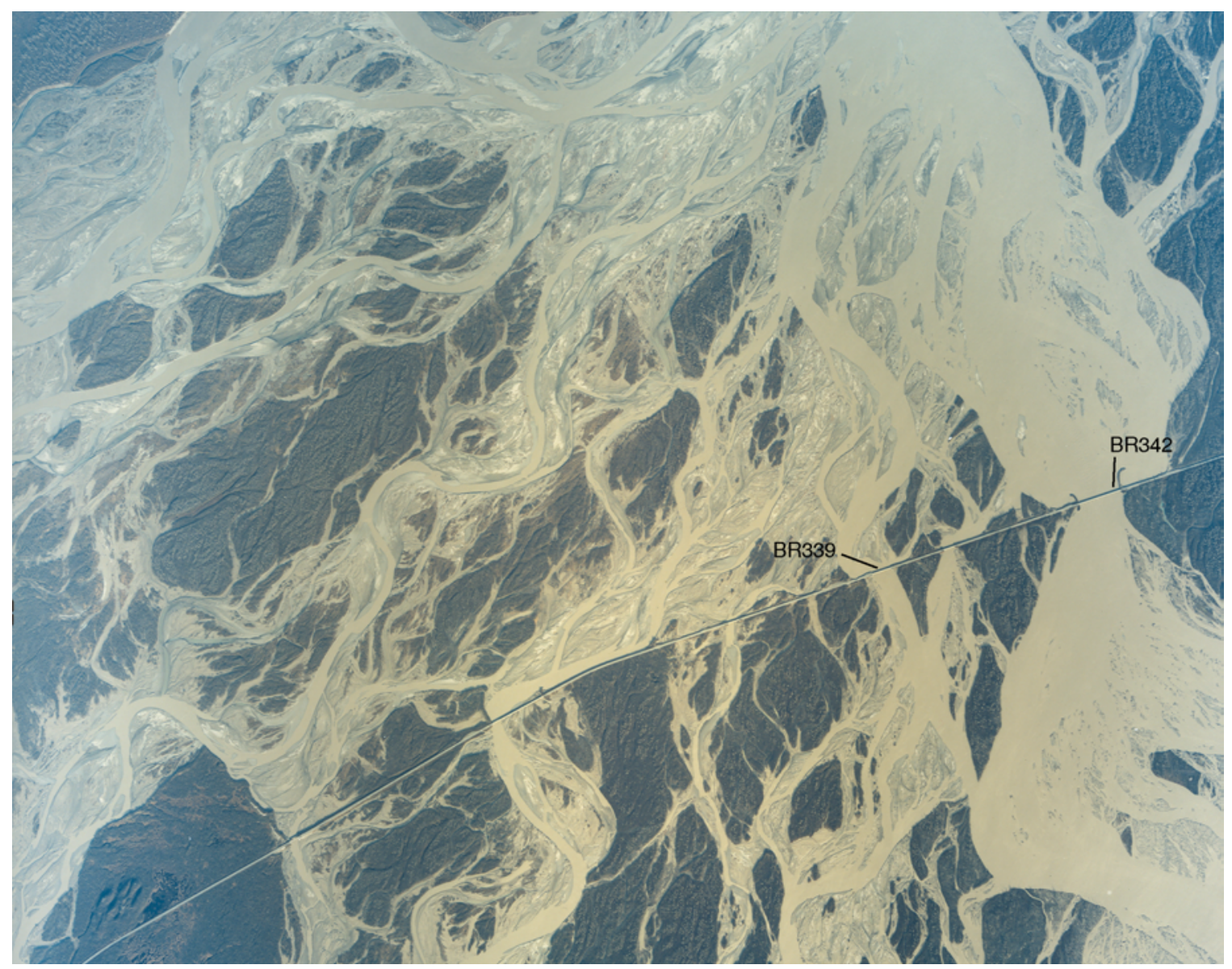

Figure 7. Aerial photography of the lower Copper River near Bridge 339 taken in October 2006. 


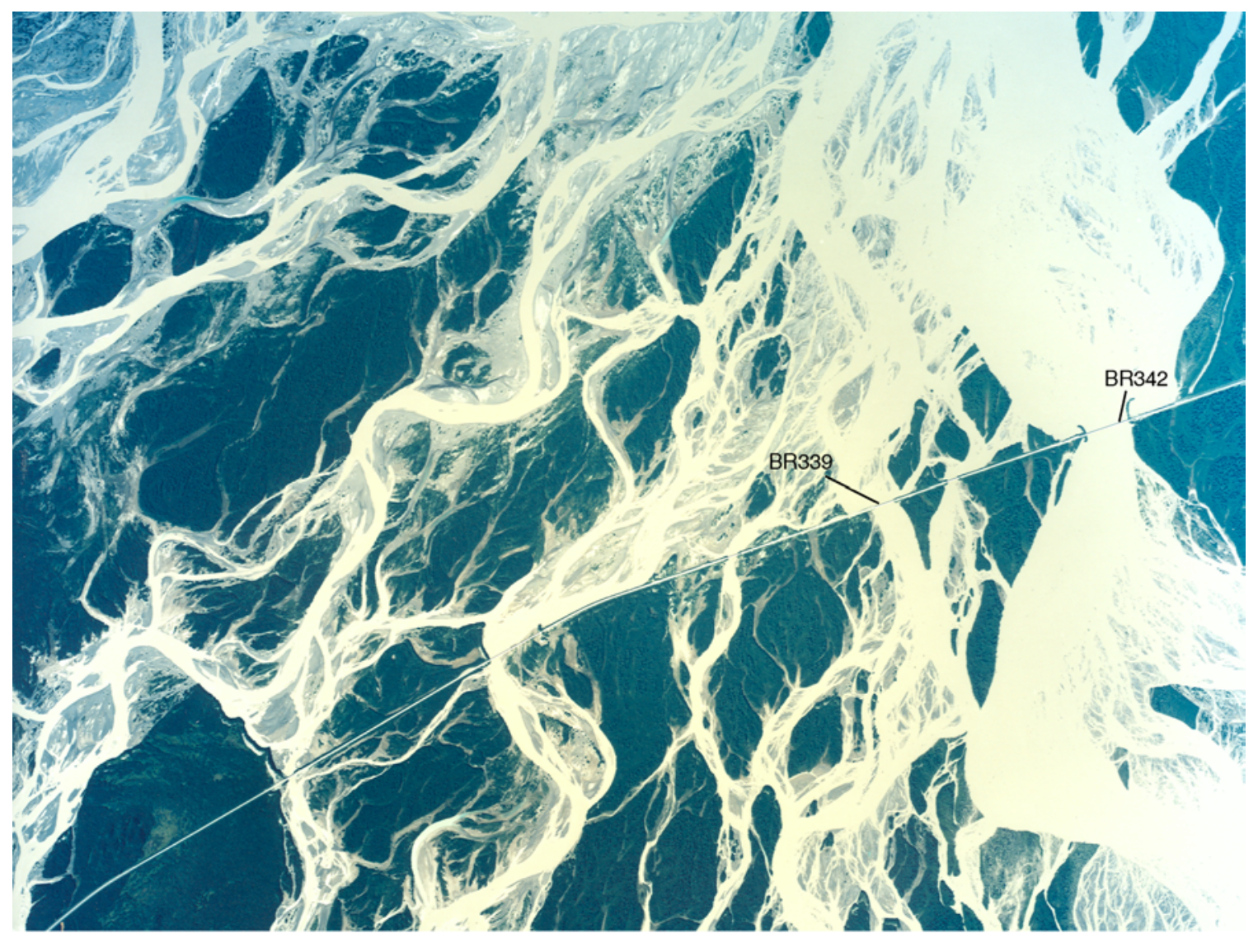

Figure 8. Aerial photography of the lower Copper River near Bridge 339 taken in August 2007. 


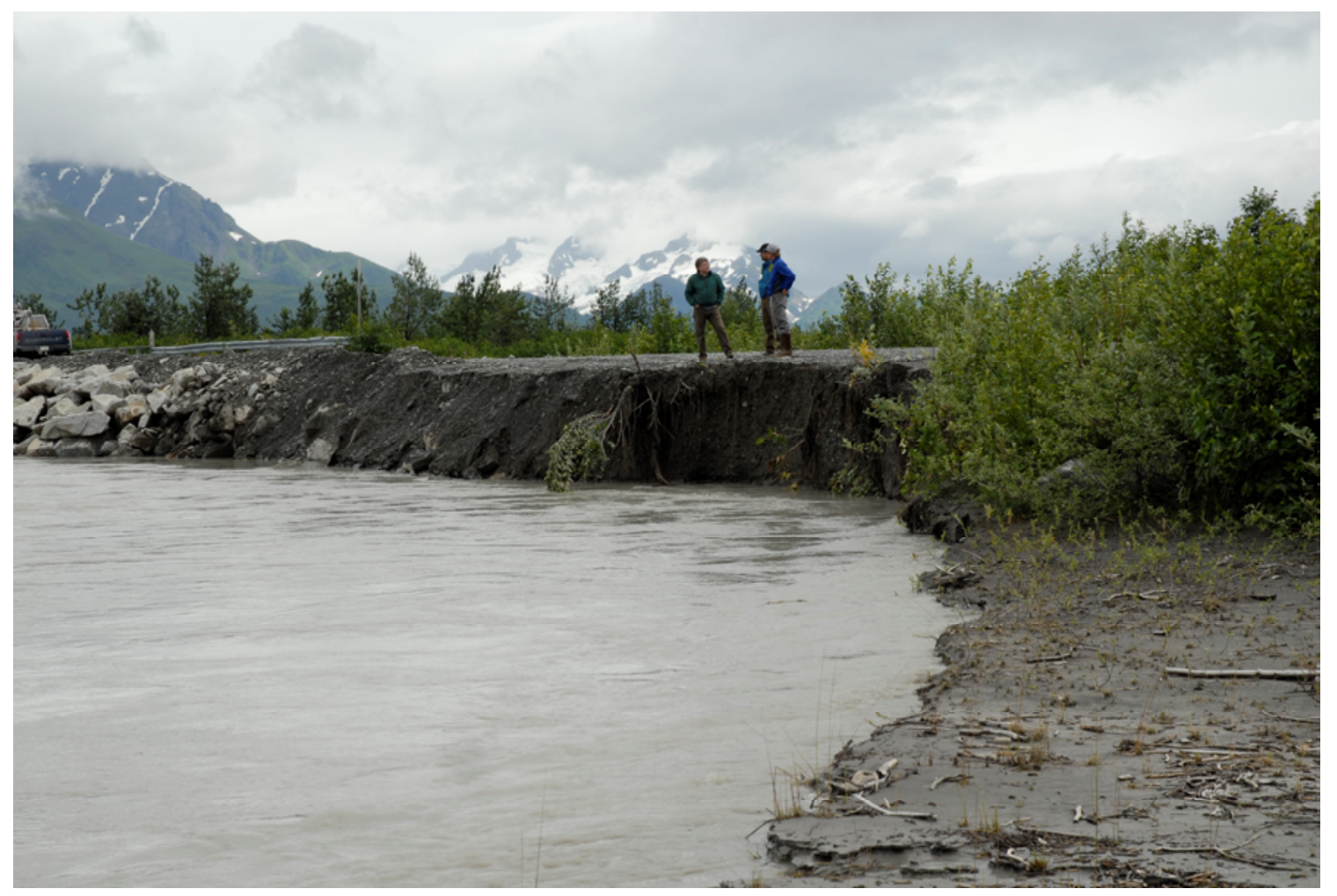

Figure 9. Photograph of the approach section to Bridge 339 showing the material that comprises the approach and the large riprap placed to protect the bank.

As a result of this channel change (and additional damage that was done to the Copper River Highway from Mile 41 to 44 in 2001), the USGS, in cooperation with AKDOT\&PF, began another study of the lower Copper River. In 2004, the first discharge measurements since 1995 were made at Bridge 339. These measurements confirmed the major channel change because the discharges measured (26,000, 20,200, and 12,500 $\left.\mathrm{ft}^{3} / \mathrm{s}\right)$ represented about 20 percent of the total flow of the Copper River. In 2005, sonars (depth sensors) were installed on piers to measure scour. Scour depths as great as $30 \mathrm{ft}$ have been recorded. From 2004 to 2008, discharge measurements at Bridge 339 have documented flows as high as $32,500 \mathrm{ft}^{3} / \mathrm{s}$, far exceeding the bridge's design discharge of $17,500 \mathrm{ft}^{3} / \mathrm{s}$. Depending on the alignment of the approach channel relative to the bridge opening, scour has varied among the piers. 
In October 2006, the Copper River Basin experienced flooding as a result of a 'pineapple express,' a low-pressure system that moved inward from the Gulf of Alaska. The resulting flood peak of $437,000 \mathrm{ft}^{3} / \mathrm{s}$ at the Million Dollar Bridge was estimated to have only a 1 to 1.5 percent chance of occurrence. The peak stage at Bridge 339 was $53.47 \mathrm{ft}$, and the estimated peak discharge was $55,000 \mathrm{ft}^{3} / \mathrm{s}$. Although there was no structural damage to Bridge 339, the flood damaged the western approach to the bridge, almost breaching the roadway, and the heavy riprap that had been placed along the approach was washed away (fig.10). Based on the inspection of the aerial photography and discharge measurements taken after the October 2006 flood, it does not appear that any long-lasting channel changes resulted from the flood.

The migration of the approach channel to Bridge 339 during August - September 2008 (figs. 11-12) also is of concern to AKDOT\&PF. The main channel now directly impacts the right downstream abutment, requiring placement of additional heavy riprap to reinforce the west abutment. If movement of the channel continues, flow will be directed towards the east approach (left bank) to the bridge, most likely creating the same conditions that occurred on the west approach.

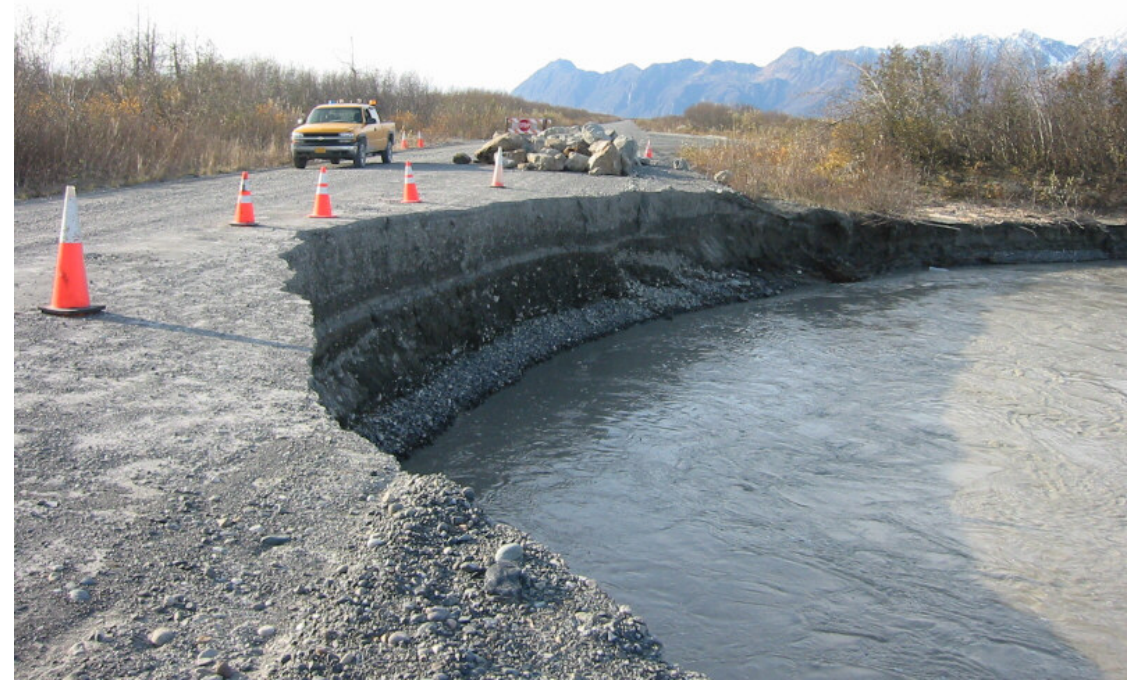

Figure 10. Photograph of west approach section to Bridge 339, showing damage from the October 2006 flood. 


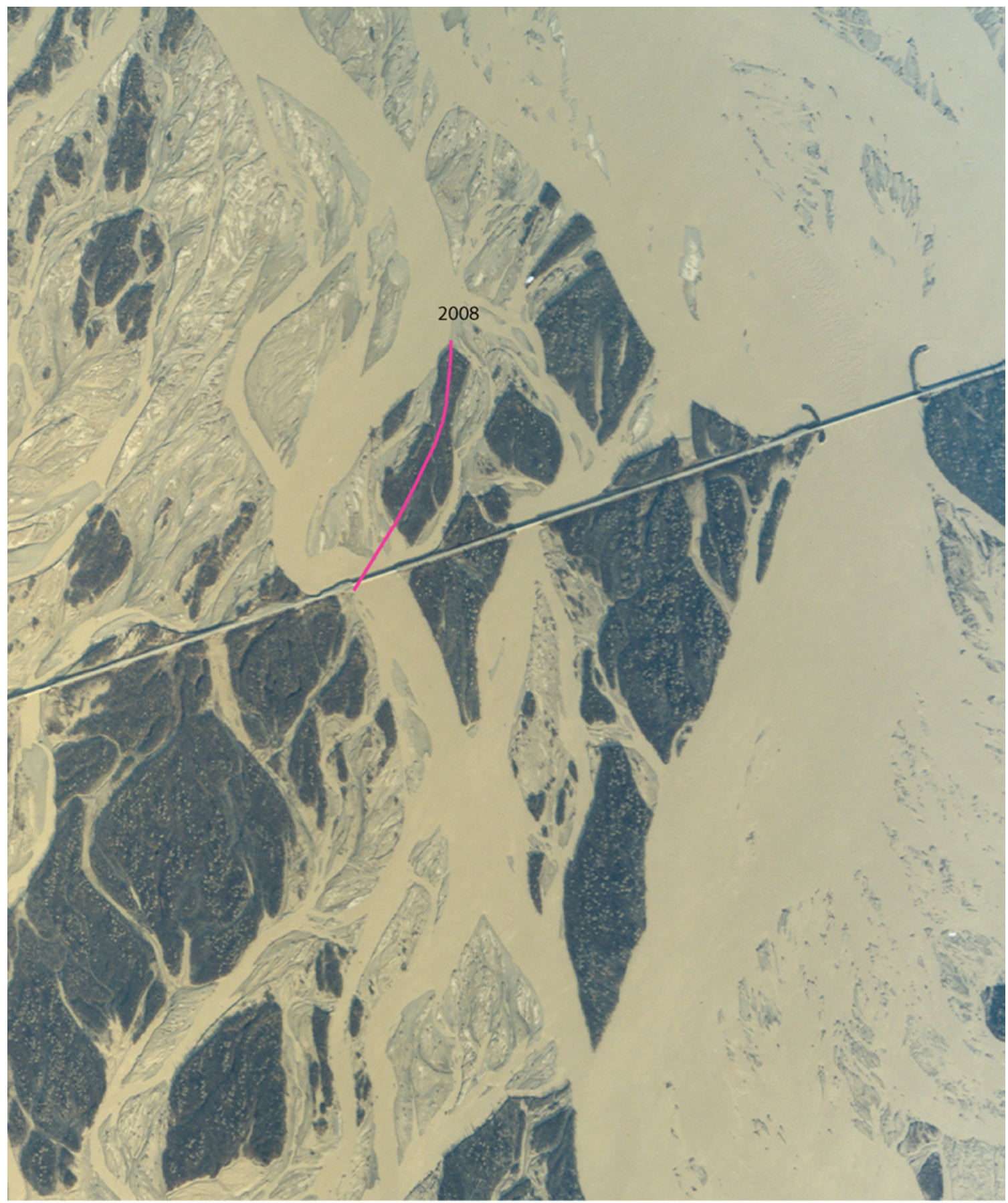

Figure 11. Aerial photography of the Bridge 339 area taken in October 2006. Red line indicates the position of the left bank in August-September 2008. 


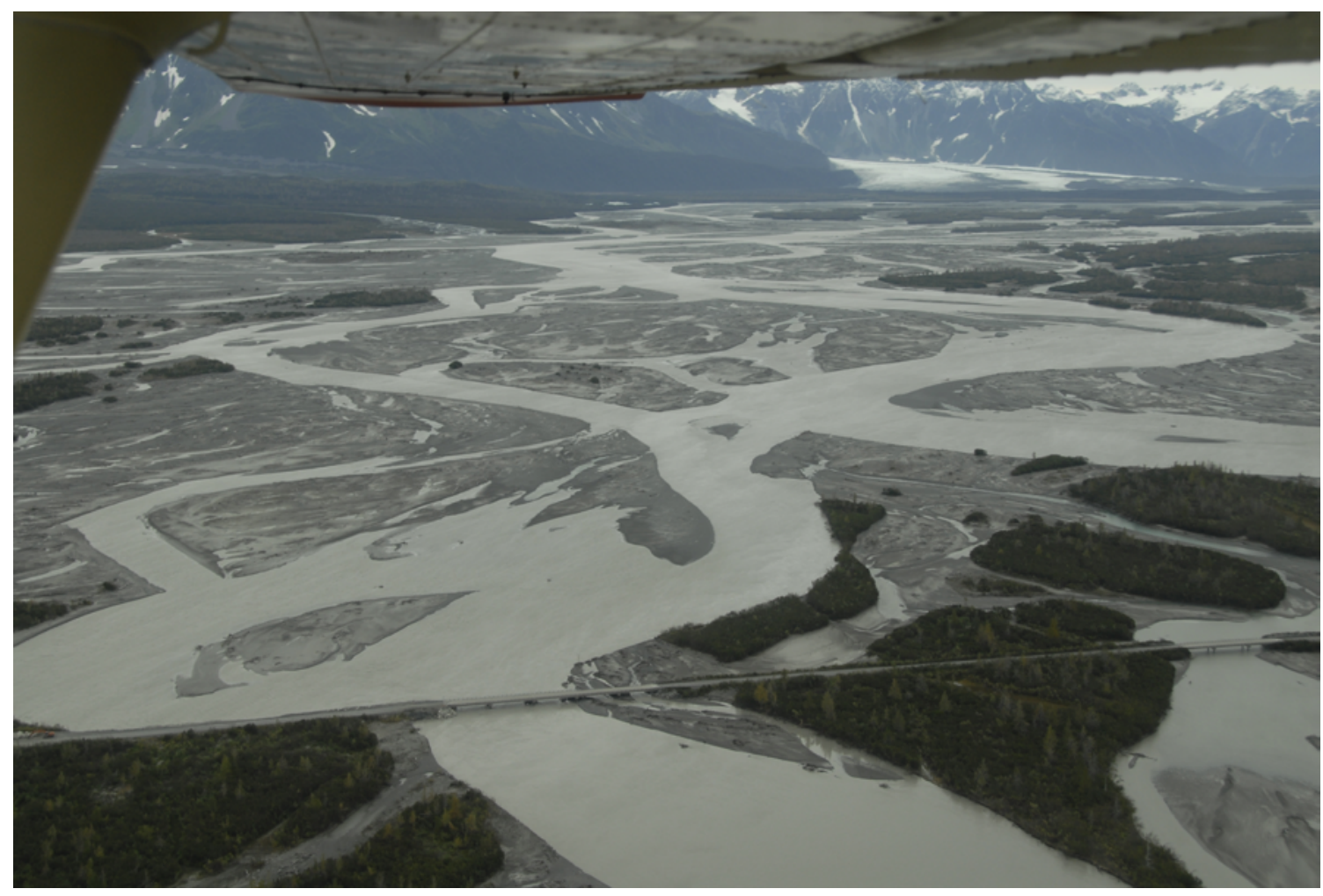

Figure 12. Photograph of Bridge 339 taken on September 29, 2008, looking upstream. The left upstream bank has eroded considerably and the main channel heads directly towards the right downstream abutment. 


\section{Potential Solutions to Scour and Erosion at the Bridge 339 Area}

The migrating approach channel and river discharges well in excess of the design discharge at Bridge 339 have and will continue to require maintenance by AKDOT\&PF at the west approach to the bridge. Additionally, the piers at Bridge 339 are subject to excessive scour and the structure itself could be at risk. The channel will continue to undercut the west approach, which consists of fine-grained material (figs. 9-10), and as a result of the undercutting, riprap will continue to be washed away and will need to be replaced. As the channel erodes in the vicinity of Bridge 339, there will be a tendency to flow into another channel towards Bridge 336 (fig. 13). Increased discharge in this channel would impact the highway in several points that have no riprap protection before passing through Bridge 336, which has a design discharge of only $8,500 \mathrm{ft}^{3} / \mathrm{s}$. The material of the roadbed between bridges 339 and 336 is easily erodible, and the road grade is lower than at Bridge 339. Thus, in addition to continued problems at Bridge 339, problems could also arise at Bridge 336 or along the highway between the two bridges if the approach channel to bridge 339 migrates to the west.

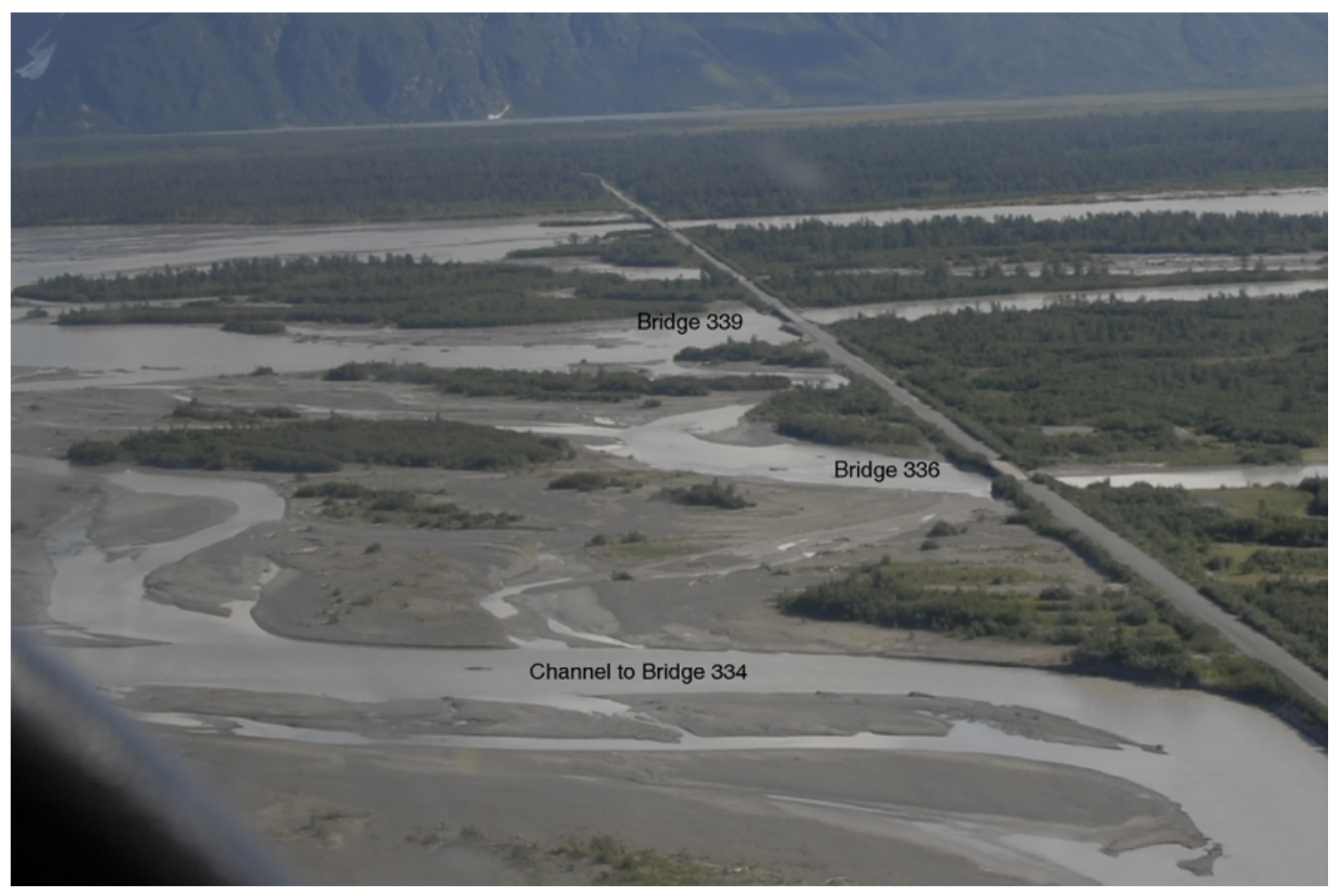

Figure 13. Photograph of the Copper River Highway taken in August 2007, looking east towards Bridge 336 and Bridge 339. Flow at Bridge 334 is 4,800 ft3/s, at Bridge 336 is 2,040 ft $3 / \mathrm{s}$, and at Bridge 339 is $24,800 \mathrm{ft} / \mathrm{s}$. 
Some solutions or betterments that have been considered for Bridge 339 are (1) constructing a 250-ft guide bank on the west upstream side of Bridge 339 to direct the water perpendicular to the bridge, (2) re-channelization or dredging of approximately $1,000 \mathrm{ft}$ of channel directly upstream of Bridge 339, and (3) extending the bridge (fig. 14). Each of these betterments would have a different effect on the hydraulic conditions in the Bridge 339 area. The USGS Multi-Dimensional Surface Water Modeling System (MD_SWMS) (McDonald and others, 2005) was used to analyze the hydraulic conditions resulting from for the proposed betterments.

MD_SWMS is a generic Graphical User Interface (GUI) developed by the USGS (McDonald and others, 2006) for hydrodynamic models. FaSTMECH, one of the computational models within MD_SWMS (Nelson and McDonald, 1997), includes a 2-dimensional, vertically-averaged model and a sub-model that calculates vertical distribution of the primary velocity and the secondary flow about the vertically averaged flow. This so-called '2.5-dimensional' approach has been shown to adequately simulate the velocity field and bed shear stress without the complexity of a fully 3-dimensional model.

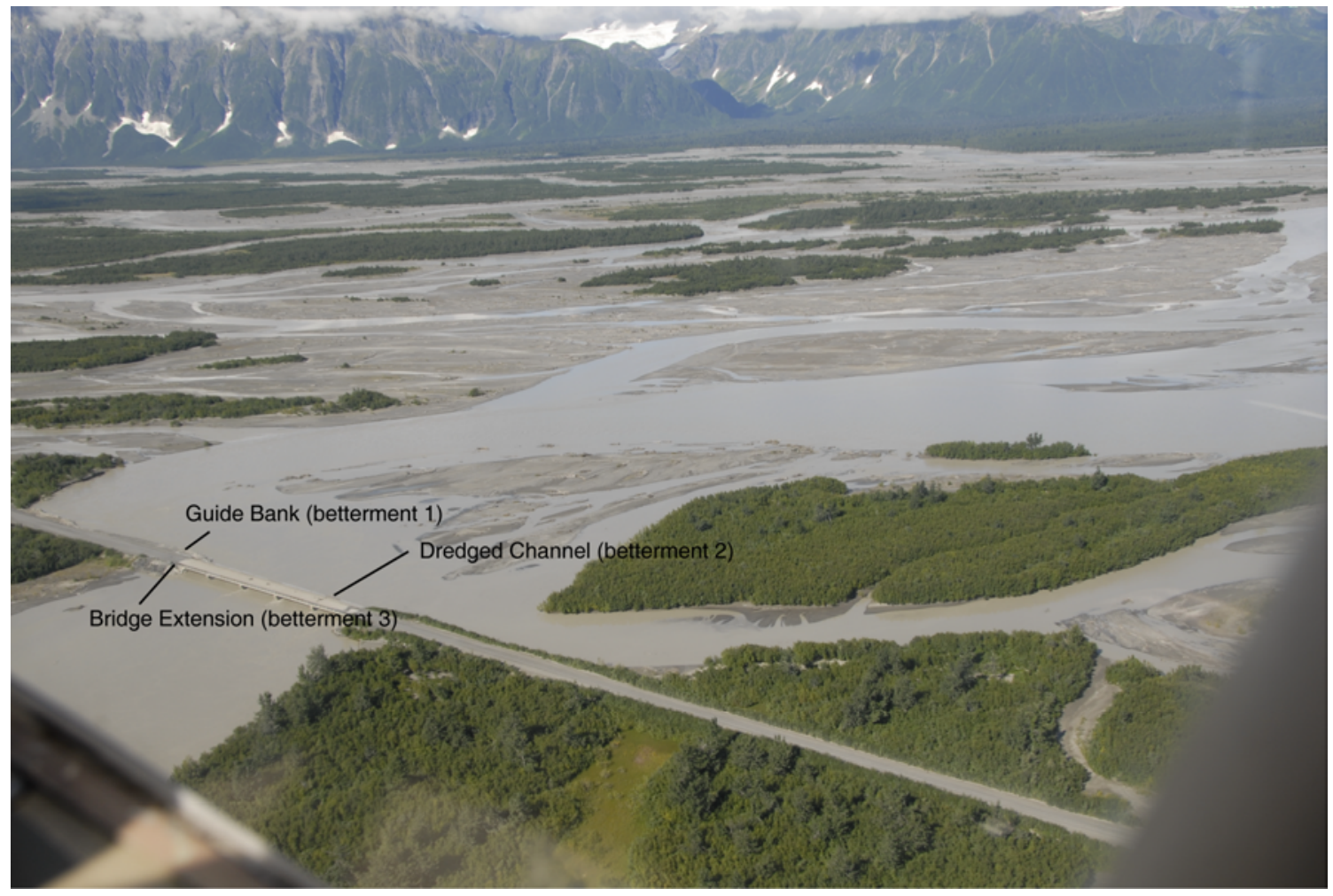

Figure 14. Photograph of Bridge 339 taken in August 2007, looking upstream. 
Minimum data requirements for the model include channel geometry, streamflow at the upstream boundary, and water-surface elevation at the downstream boundary (appendix 1). The physical assumptions of the model are that flow is steady, incompressible, and hydrostatic (vertical accelerations are neglected), and that turbulence is adequately treated by relating Reynolds stresses to shear using an isotropic eddy viscosity (Nelson and others, 2003).

MD_SWMS was used to simulate the following scenarios at Bridge 339:

(1) channel conditions in 2006 with no betterments for model calibration,

(2) construction of a 250-ft long guide bank at the upstream west abutment of the bridge,

(3) re-channelization or dredging of the existing channel upstream of the bridge, and

(4) a $240 \mathrm{ft}$ extension of Bridge 339. For each scenario, a discharge of 32,500 $\mathrm{ft}^{3} / \mathrm{s}$ was assumed/simulated, the highest flow that has been measured at the bridge. Water-surface elevation at the bridge $(51.21 \mathrm{ft})$ was known at this discharge. The upstream and downstream water-surface elevations were determined on the basis of the water-surface slope determined from the LIDAR data, which was obtained at a discharge of 20,200 $\mathrm{ft}^{3} / \mathrm{s}$ and a water-surface elevation of $50.84 \mathrm{ft}$. A bed material size of $8 \mathrm{~mm}$ (based on data collected by Brabets, 1997) was used as input to MD_SWMS to compute the critical shear stress of the river bed. Convergence for each of the four scenarios simulated by MD_SWMS was within acceptable limits.

\section{Calibration Conditions}

Input conditions for the simulated calibration discharge are presented in table 1 and appendix A. The output from MD_SWMS indicated an averaged predicted watersurface elevation of $51.94 \mathrm{ft}$ versus the observed water surface of $51.08 \mathrm{ft}$ at the bridge. Predicted velocities ranged from 3.4 to $8.6 \mathrm{ft} / \mathrm{s}$ along the right bank and the approach to Bridge 339 (fig. 15). Average velocities measured downstream for the calibration discharge ranged from 6.4 to $6.8 \mathrm{ft} / \mathrm{s}$. Modeled shear stress values ranged from 0.21 to $1.04 \mathrm{lb} / \mathrm{ft}^{2}$ (fig. 16). On the basis of previous work by Julien (1998), the critical shear stress for mobility of bed material with a diameter of $0.31 \mathrm{in}$. would be $0.12 \mathrm{lb} / \mathrm{ft}^{2}$. Thus, the modeled reach would be considered a mobile bed. Based on field observations, the channel is constantly changing, thus verifying to a certain extent, the output from MD_SWMS. Although the channel is changing, it was felt the model could be used to simulate the various betterments for non-design purposes. 
Table 1. Boundary conditions and model parameters used for the simulation of the calibration discharge of 32,500 ft3/s at Bridge 339, Copper River Highway, Alaska.

[ $\mathrm{ft}^{3} / \mathrm{s}$, cubic foot per second; ft, foot; $\mathrm{ft} / \mathrm{ft}$, foot per foot; $\mathrm{ft}^{2} / \mathrm{s}$, foot squared per second]

\section{Boundary conditions}

\begin{tabular}{lr}
\hline Discharge & $32,500 \mathrm{ft}^{3} / \mathrm{s}$ \\
Downstream starting water-surface elevation & $49.86 \mathrm{ft}$ \\
Channel slope & 0.001 \\
\hline
\end{tabular}

Model parameters

$\begin{array}{ll}\text { Number of grid cells } & 31,411\end{array}$

Grid cell spacing in stream-wise and stream-

$16.4 \mathrm{ft}$ normal directions

Lateral eddy viscosity

$0.054 \mathrm{ft}^{2} / \mathrm{s}$

Drag coefficient

0.007 


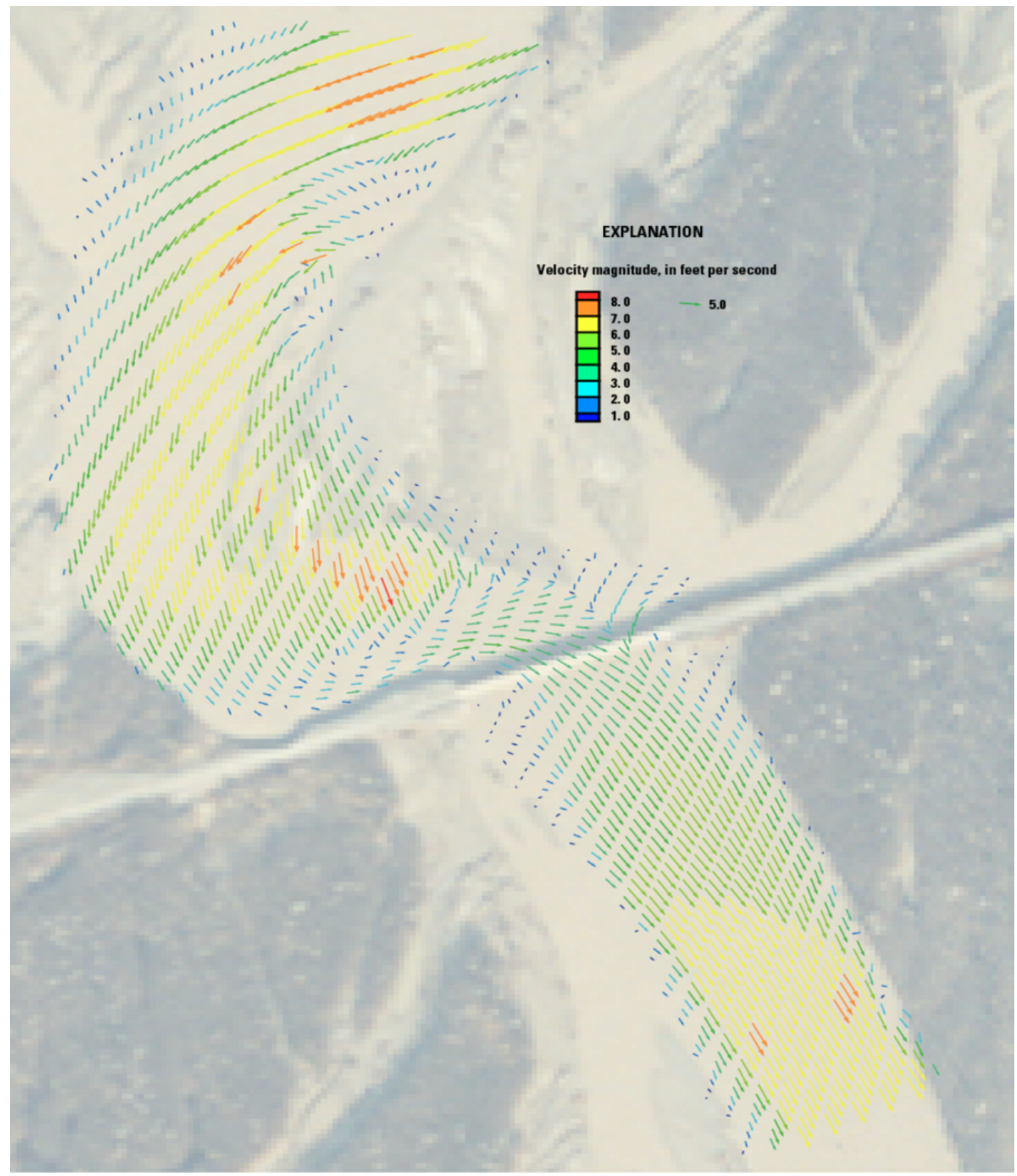

Figure 15. Output from MD_SWMS showing velocity vectors at the Bridge 339 reach based on a flow of 32,500 ft3/s. Aerial photograph taken October 15, 2006, when flow at Bridge 339 was approximately $25,000 \mathrm{ft}^{3} / \mathrm{s}$. 


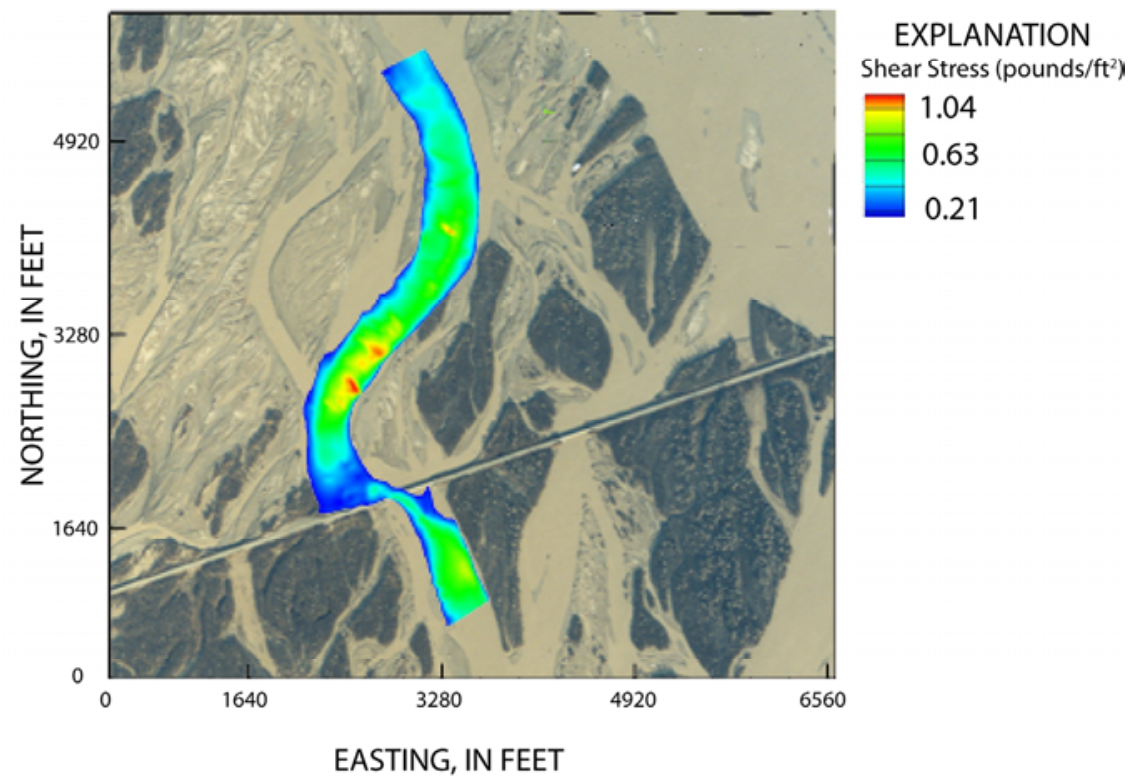

Figure 16. Output from MD_SWMS showing shear stress at the Bridge 339 reach based on a flow of $32,500 \mathrm{ft} 3 / \mathrm{s}$.

\section{Guide Bank}

As proposed, the guide bank would be $250 \mathrm{ft}$ long and constructed on the west end of the bridge. The guide bank would be perpendicular to the roadway and then angle slightly to the west. The desired effect of the guide bank would be to align the direction of flow perpendicular to Bridge 339. However, the output from MD_SWMS did not indicate this change in flow direction would take place. Velocities, velocity vectors, and bed shear stresses were nearly identical to current conditions, which would indicate that most of the flow still would be directed towards the approach and not towards the bridge (fig. 15). The simulation results indicated that the proposed guide bank would not be long enough to keep the approach channel from impacting the right bank bridge approach. A possible negative impact of the guide bank, based on the output from MD_SWMS, would be to increase the water-surface elevation along the right bank (fig. 17). Such an increase in water-surface elevation could possibly increase flow towards Bridge 336. However, no attempt was made to determine the amount of flow towards this bridge. A guide bank greater than $250 \mathrm{ft}$ would limit flow towards Bridge 336. 


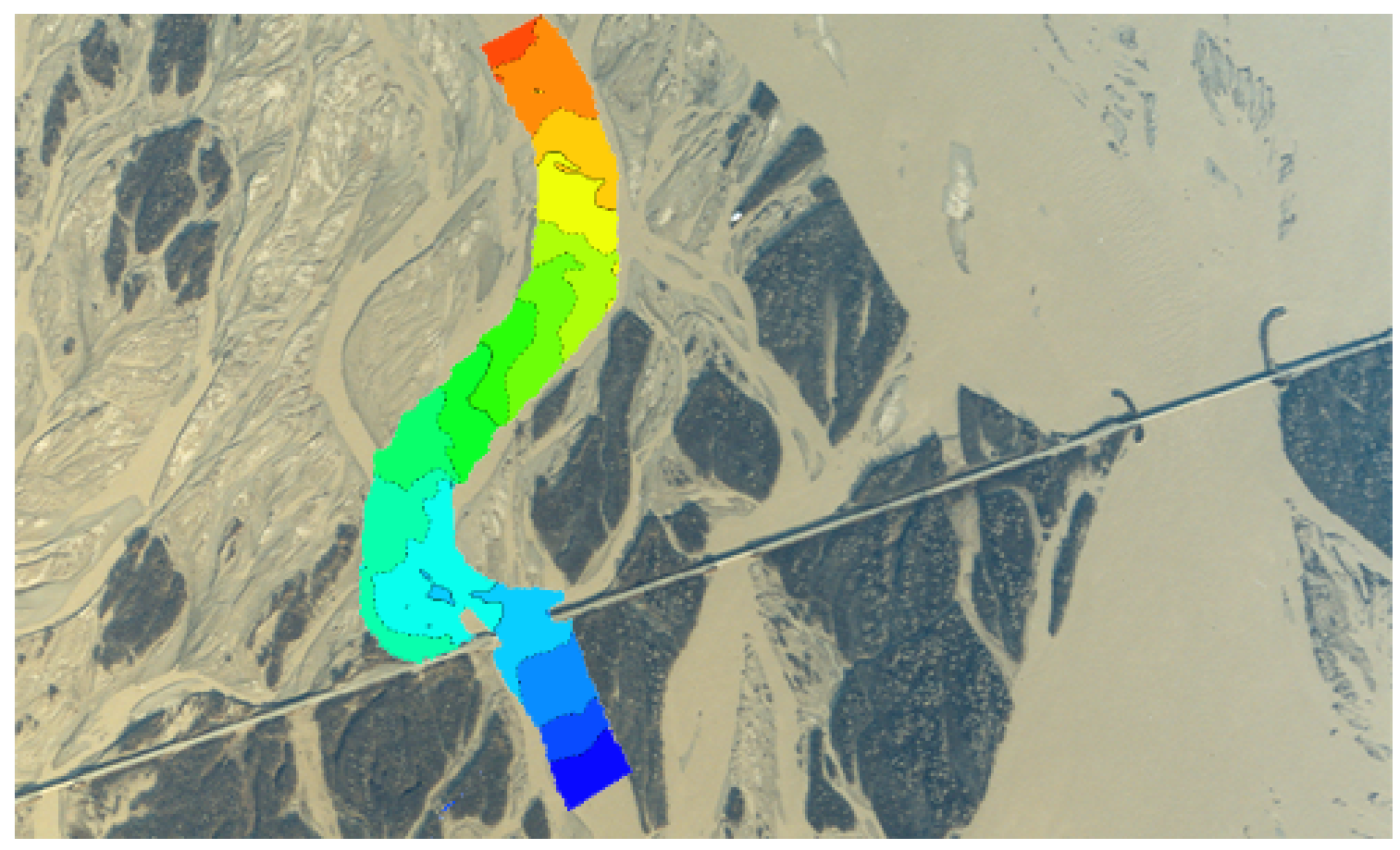

\section{EXPLANATION}

Water-surface elevation, in feet

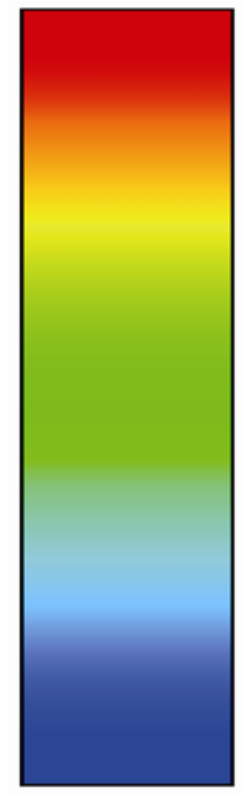
56.70
56.23
55.81
55.35
54.89
54.43
54.00
53.54
53.08
52.62
52.20
51.74
51.28
50.82
50.39
49.93

Figure 17._-Output from MD_SWMS showing water-surface elevations at Bridge 339 based on a discharge of $32,500 \mathrm{ft}^{3} / \mathrm{s}$ and construction of a $250 \mathrm{ft}$ guide bank. 


\section{Re-Channelization}

Another proposed mitigation approach is re-channelization or dredging upstream of the bridge. The proposed dredging would begin at or near the upstream center of Bridge 339, would be 1,000 ft length, $150 \mathrm{ft}$ wide, and 5 to $8 \mathrm{ft}$ below the 2006 upstream bed elevation of $36 \mathrm{ft}$, and would be aligned perpendicular to the bridge opening. The desired effect of this option is to encourage the approach channel to align itself with the bridge opening. Using these geometric parameters, the channel bathymetry was modified and input to MD_SWMS.

This simulation showed the highest velocities through the dredged channel, indicating that most of the flow was through this channel and perpendicular to the bridge (fig. 18). It is important to note, however, that one the basis of calculated shear stresses, the entire bed is mobile. Thus, the dredged channel could fill in when the bed is mobilized during high flow and the original channel would be re-occupied.

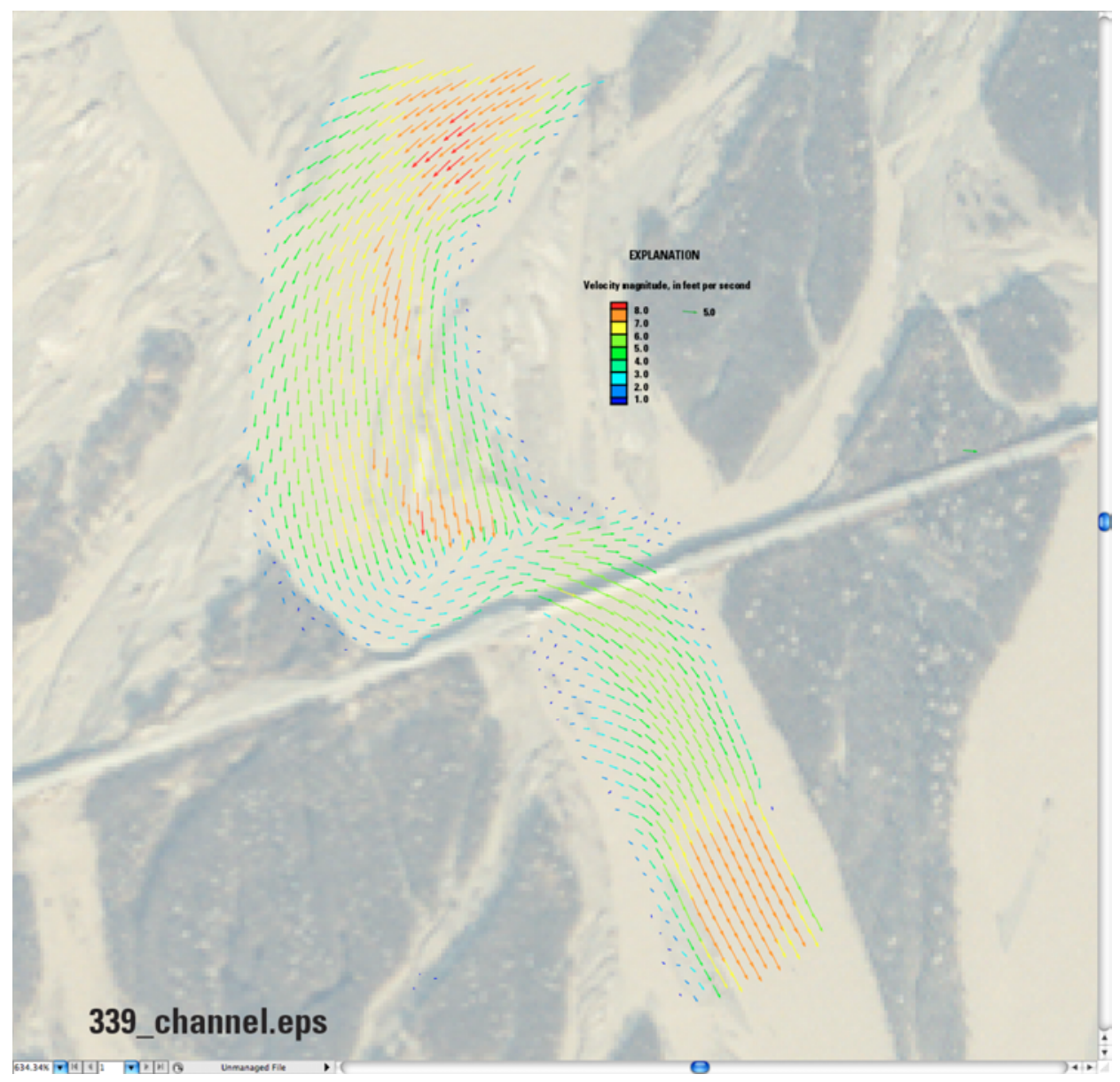

Figure 18. Output from MD_SWMS showing velocity vectors at Bridge 339 based on a flow of $32,500 \mathrm{ft} / \mathrm{s}$ and re-channelization upstream from bridge. 


\section{Bridge Extension}

The third betterment analyzed was an extension of Bridge 339. Currently, it would appear that any extension of Bridge 339 should be to the west, but a thorough analysis of channel migration should be done before a final decision is made. Because the main channel is currently on the right bank and a bridge extension would consist of $80-\mathrm{ft}$ sections, for this scenario, a $240 \mathrm{ft}$ extension of Bridge 339 to the west was used for modeling purposes.

If Bridge 339 were extended $240 \mathrm{ft}$ to the west, simulation results showed that water velocity and the corresponding velocity vectors were lower than the calibration conditions and were more uniform across the channel (fig. 19). Thus, flow would be more nearly centered through the bridge. On the basis of calculated shear-stress values, the channel would still be mobile, but the potential for scour would be reduced due to the lower shear-stress values. Based upon surveyed cross sections from 2005 to 2008, the flow tends to occupy discrete portions of the channel rather than its entire width. If this trend continues, an increase in the bridge opening would do little to mitigate scour. 


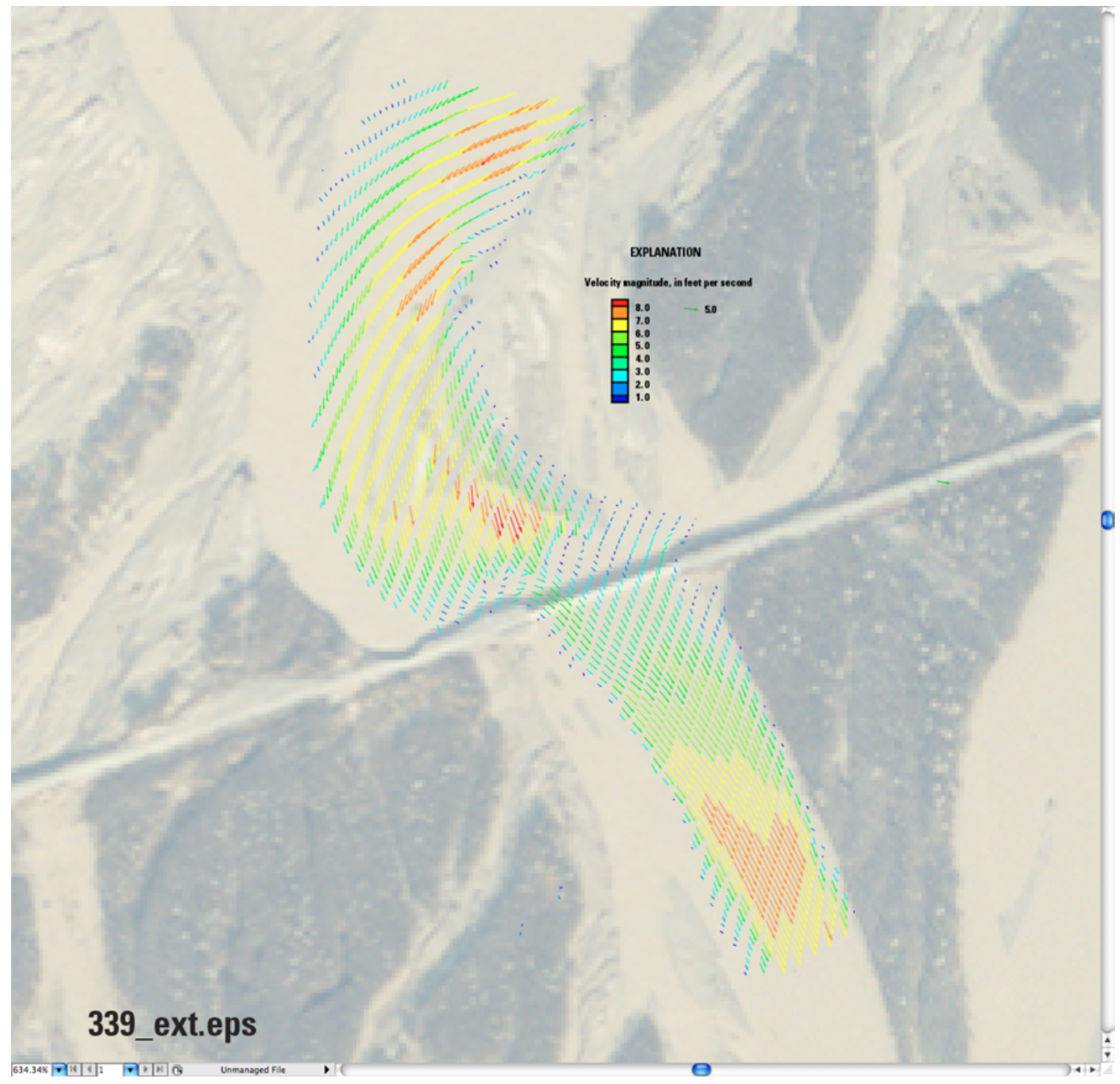

Figure 19. Output from MD_SWMS showing velocity vectors at Bridge 339 based on a flow of $32,500 \mathrm{ft}^{3} / \mathrm{s}$ and extending the bridge $240 \mathrm{ft}$ to the west. 


\section{Summary and Additional Considerations}

Bridge 339, located at Mile 36 of the Copper River Highway, Alaska, has undergone significant scour at its piers, abutments, and approach due to a major channel shift of the Copper River in 2001 that resulted in flows higher than the design discharge for the bridge. Under current hydraulic conditions, considerable maintenance will be required to protect the bridge and approach. To insure the integrity of the bridge and reduce maintenance costs, three betterments have been proposed for Bridge 339. The hydraulic conditions associated with these betterments were analyzed using the USGS Multi-Dimensional Surface Water Modeling System (MS_SWMS).

A proposed 250-foot long guide bank (betterment 1) would not be long enough to affect hydraulic conditions at the bridge. A possible negative impact of the guide bank would be to increase the water-surface elevation along the right bank, resulting in higher flow towards another bridge. If the channel upstream of Bridge 339 were dredged (betterment 2), simulation results indicate that most of the flow would pass through the new channel and perpendicular to the bridge. Because the entire bed is mobile, however, the dredged channel could fill back during periods of high flow and the original channel would be re-occupied. If Bridge 339 were extended 240 feet to the west (betterment 3), the simulated velocity, and the corresponding velocity vectors would be lower than the current conditions and more uniform across the channel. The channel still would be considered mobile, but the potential for scour would be reduced due to the lower shearstress values. Without guide banks of sufficient length on both banks, it is still possible for the approach channel to be misaligned relative the bridge opening and scour of the approach to continue despite the increased length of the bridge opening.

Two potential scenarios were not addressed in this report. First, if the main channel that leads to Bridge 342 (upstream of Bridge 339) were to shift and direct more flow to the channel leading to Bridge 339, the flow capacity of Bridge 339 would be exceeded more frequently than at present and excessive scour at the piers or abutments at Bridge 339 could occur. Secondly, the effects of the movement of the approach channel to Bridge 339 that occurred in August - September 2008 was not considered. The main channel now directs flow at the right downstream abutment, requiring the placement of additional heavy riprap to reinforce the abutment. If movement of the channel continues, flow will be directed toward the east approach (left bank) to the bridge, most likely creating the same conditions that occurred on the west approach to the bridge. 


\section{References Cited}

Brabets, T.P., 1997, Geomorphology of the Lower Copper River, Alaska: U.S. Geological Survey Professional Paper 1581, 89 p.

Julien, P.Y., 1998, Erosion and sedimentation: Cambridge University Press, 280 p.

McDonald, R.R., Bennett, J.P., and Nelson, J.M., 2005, Multi-dimensional surface water modeling system user's guide: U.S. Geological Survey Techniques and Methods Report, book 6, section B, chapter 6, 156 p., accessed at http://wwwbrr.cr.usgs.gov/gst1/WebHelp_Pro/MD_SWMS.htm

McDonald, R.R., Bennett, J.P., and Nelson, J.M., 2006, Multi-dimensional surface water modeling user's guide: U.S. Geological Survey Techniques and Methods, book 6, section B, chapter 6, 156 p.

Nelson, J.M., and McDonald, R.R., 1997, Mechanics and modeling of flow and bed evolution in lateral separation eddies, Glen Canyon Environmental Studies Report, $69 \mathrm{p}$.

Nelson, J.M., Bennett, J.P., and Wiele, S.M., 2003, Flow and sediment-transport modeling, in Kondolf, G.M., and Piegay, H., eds., Tools in fluvial geomorphology: England, Wiley, p. 539-576. 


\section{Appendix A. Input requirements and calibration procedures for the Multi-Dimensional Surface Water Modeling System (MD_SWMS) as applied at Bridge 339 of the Copper River Highway, Alaska}

The most important input to MD_SWMS is a good digital elevation model (DEM) of the area of interest. In the Bridge 339 area, there is constant scour and fill and channels are continuously shifting. A DEM was created based on the following data sets: LIDAR data collected in June 2005, channel bathymetry collected using a single-beam fathometer in June 2006, channel bathymetry collected using a multi-beam fathometer in August 2006, channel bathymetry collected using a multi-beam fathometer in June 2007, and acoustic Doppler current profiler (ADCP) measurements made in 2006 and 2007.

The bathymetry data collected in 2006 and 2007, along with the ADCP data were combined into one file. Using an ARCGIS procedure called POINTINTERP, a grid of the main channel to Bridge 339 was created. POINTINTERP interpolates a grid from a set of points using a specified neighborhood. The inverse distance weighted interpolation technique was used and a grid cell size of $16.4 \mathrm{ft}$ was used. The grid created by POINTINTERP was then output to an ascii file. Using tools available in MD_SWMS, the main channel to Bridge 339 was cut-out of the LIDAR data and replaced by the channel created by the POINTINTERP procedure.

After the main channel in the Bridge 339 was digitally constructed, the elevations of the gravel bars in the area were set to the elevations of the vegetated islands. Although gravel bars and small channels are scattered throughout the approach section leading to Bridge 339, it was assumed that only a small amount of flow goes through these channels. This assumption simplified the runs of MD_SWMS by showing only the main channel.

Calibration is the process of adjusting model parameters within reasonable limits to obtain the best fit of the simulation results to measured data. This process involves repeatedly adjusting a parameter, running the model, and inspecting differences between model output and measured data with the objective of minimizing these differences. In this study, several parameters were adjusted during the calibration process.

The drag coefficient was adjusted until the simulated water-surface slope through the modeled reach reproduced as closely as possible the measured water surface. Physically, this process is equivalent to ensuring that the roughness value used in MD_SWMS accurately simulates the head loss in the channel over long reaches. Because the downstream water-surface elevation was set as a model boundary condition, this process insured that the reach-averaged water-surface slope simulated by MD_SWMS matched the measured values. The final value used for the drag coefficient was 0.007 .

MD_SWMS incorporates a lateral eddy viscosity (LEV) to represent lateral momentum exchange due to turbulence or other variability that is not generated at the bed (Nelson and others, 2003). The computed LEV value was applied uniformly throughout the modeling reach for each calibration streamflow. Similar to the drag coefficient, the LEV was adjusted within reasonable limits (based on field data) during the calibration process to reproduce as closely as possible the measured water-surface elevation. The final value for the $\mathrm{LEV}$ was $0.54 \mathrm{ft}^{2} / \mathrm{s}$. 
As an additional check, model convergence is evaluated by MD_SWMS by comparing the predicted model discharge to the observed specified discharge for a cross section. For this study, MD_SWMS was run for 500 iterations. If the percent deviation from the normalized discharge is within \pm 3 percent, the convergence was considered acceptable. If the convergence was greater than \pm 3 percent, the values for the drag coefficient and LEV were checked to make sure they were within reasonable limits. Next, the relaxation parameters E (water-surface elevation), U (velocity), and A (global slope) were adjusted. For this study, model calibration was considered acceptable if the predicted versus observed water surface elevations were within $\pm 1.6 \mathrm{ft}$ and convergence was within \pm 3 percent. 
Publishing support provided by the U.S. Geological Survey Publishing Network, Tacoma Publishing Service Center

For more information concerning the research in this report, contact the Director, Alaska Science Center

U.S. Geological Survey 4210 University Dr.

Anchorage, Alaska 99508-4650

http://alaska.usgs.gov 


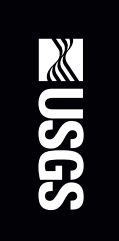

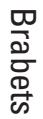

官

온



(1)

뫃

을

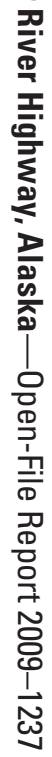

